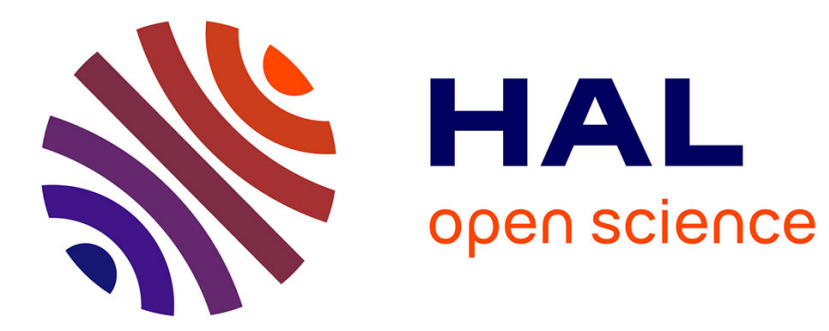

\title{
Probe size study of apatite irradiation in stem
}

\author{
José Reyes-Gasga, Christian Rey, Jean Michel, Etienne Brès
}

\section{To cite this version:}

José Reyes-Gasga, Christian Rey, Jean Michel, Etienne Brès. Probe size study of apatite irradiation in stem. European Physical Journal: Applied Physics, 2014, vol. 67 (n² 2), pp. 1-6. 10.1051/epjap/2014130104 . hal-01194744

\section{HAL Id: hal-01194744 \\ https://hal.science/hal-01194744}

Submitted on 7 Sep 2015

HAL is a multi-disciplinary open access archive for the deposit and dissemination of scientific research documents, whether they are published or not. The documents may come from teaching and research institutions in France or abroad, or from public or private research centers.

$$
\text { Copyright }
$$

L'archive ouverte pluridisciplinaire HAL, est destinée au dépôt et à la diffusion de documents scientifiques de niveau recherche, publiés ou non, émanant des établissements d'enseignement et de recherche français ou étrangers, des laboratoires publics ou privés. 


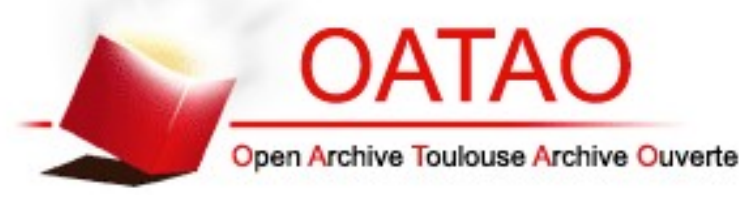

\section{Open Archive TOULOUSE Archive Ouverte (OATAO)}

OATAO is an open access repository that collects the work of Toulouse researchers and makes it freely available over the web where possible.

This is an author-deposited version published in : http://oatao.univ-toulouse.fr/ Eprints ID : 14236

To link to this article : DOI:10.1051/epjap/2014130104

URL : http://dx.doi.org/10.1051/epjap/2014130104

To cite this version : Brès, Étienne F. and Reyes-Gasga, José and Rey, Christian and Michel, Jean Probe size study of apatite irradiation in stem. (2014) The European Physical Journal Applied Physics, vol. 67 (n²). pp. 1-6. ISSN 1286-0042

Any correspondance concerning this service should be sent to the repository administrator: staff-oatao@listes-diff.inp-toulouse.fr 


\title{
Probe size study of apatite irradiation in stem
}

\author{
Étienne F. Brès ${ }^{1, a}$, José Reyes-Gasga ${ }^{1, b}$, Christian Rey², and Jean Michel ${ }^{3}$ \\ ${ }^{1}$ Unité des Matériaux et Transformation (UMET), Université des Sciences et Technologies de Lille, Bâtiment C6, \\ 59650 Villeneuve d'Ascq, France \\ 2 École Nationale Supérieure des Ingénieurs en Arts Chimiques et Technologiques Cirimat-Ensiacet, Ensiacet 4 allée \\ Émile Monso, BP44362, 31030 Toulouse cedex 4, France \\ ${ }^{3}$ Laboratoire de Recherche en Nanosciences LRN EA4682, UFR Sciences Université de Reims, 21, rue Clément Ader, \\ 51685 Reims cedex 02, France
}

\begin{abstract}
The effect of electron beam irradiation of stoichiometric hydroxyapatite $\left(\mathrm{Ca}_{10}\left(\mathrm{PO}_{4}\right)_{6}(\mathrm{OH})_{2}\right.$, HAP) is investigated using electron energy loss spectroscopy (EELS) in the scanning transmission electron microscope (STEM) mode equipped with a $\mathrm{LaB}_{6}$ gun. Initial irradiation at $160 \mathrm{~A} \mathrm{~cm}^{-2}$ dose rate shows no modification of the low loss spectra. No difference of mass loss for $\mathrm{Ca}, \mathrm{O}$ and $\mathrm{P}$ is observed for two different probe diameters: $4 \mathrm{~nm}\left(\right.$ dose rate $\left.=160 \mathrm{~A} \mathrm{~cm}^{-2}\right)$ and $24 \mathrm{~nm}\left(\right.$ dose rate $\left.=70 \mathrm{~A} \mathrm{~cm}^{-2}\right)$. Furthermore no formation of $\mathrm{CaO}$ is observed for both experimental conditions. It is proposed that the low values of both electron dose rates and doses (from 350 to $2400 \mathrm{C} \mathrm{cm}^{-2}$ ) avoid mass loss. At the higher dose rate obtained with a field emission gun (FEG), transformations are observed for the lowloss signal as well as for the $\mathrm{Ca}, \mathrm{P}$ and $\mathrm{O}$ signals. These results might be very useful for the future studies of apatite particles at the nanoscale.
\end{abstract}

\section{Introduction}

Apatites, mainly hydroxyapatite $\left(\mathrm{Ca}_{10}\left(\mathrm{PO}_{4}\right)_{6}(\mathrm{OH})_{2}\right.$, HAP), are the main constituents of teeth and bones [1] in which they constitute the nanoscale elements of the tissues $[2,3]$. It is also used as such as biomaterials (e.g., [4]) or in substitutes both as solid materials and surface coatings [5]. Therefore, their study, analysis and improvements are very important in the medical and biomaterials fields. On the other hand, transmission electron microscopy (TEM) characterization, both in the mode of high resolution electron microscope (HRTEM) and scanning transmission electron microscopy (STEM), is necessary for studying apatite crystals at the nanoscale $[6,7]$. These techniques include: space group determination, defect characterization and surface characterization [8,9]. However, during TEM/STEM observations, organic as well as inorganic samples can undergo onto a series of electron beam damage phenomena: heating, electrostatic charging, ionization damage (radiolysis), displacement damage, sputtering and hydrocarbon contamination [10-15].

a e-mail: etienne.bres@univ-lille1.fr

b Present address: Instituto de Física, UNAM, Circuito de la Investigación s/n, Ciudad Universitaria, 04510 Coyoacan, México, D.F.
Apatite irradiated with an electron beam shows interesting behaviors depending on the characteristics of the irradiation $[7,13,14,16-18]$. So it is important to understand the effect of the electron irradiation on the apatite samples as well as for other materials [10-13,16-19].

One of the techniques available in the TEM is the electron energy loss spectroscopy (EELS). The EELS technique analyses the energy loss by the incident beam when it goes through the sample. Even damage can be more sensitive and quantifiable when it is analyzed by EELS [20]. EELS experiments have also been performed on HAP and other calcium phosphates [20-24]. fold:

The interest in using EELS for study a sample is many-

(1) Defining the extent of the reliable information that one can obtain in a microscope when analyzing our sample. Is the sample observed genuine or is it damage? As long term effects (several minutes) can easily be identified, it is impossible to identify the damage that occurs during the very first seconds of observation $[14,17,19]$;

(2) Optimizing the analysis process in order to obtain the maximum information;

(3) The damage process itself can yield information on the sample studied. For example: phase transformation $[7,16,18,25]$, geochronology $[11,26]$. 


\section{Dose rate (fluence rate) and dose (fluence)}

Experiments at various dose rates $[12,20]$ have shown a significant dependence of the extent and type of damage at a particular fluence or the fluence rate itself. Nanovoids are formed on the faces of the crystals below $1.6 \mathrm{~A} \mathrm{~cm}^{-2}$ $[13,27]$. These voids can be subsequently filled after prolonged irradiation [14]. This shows a structural destruction without material loss. Above $1.6 \mathrm{~A} \mathrm{~cm}^{-2}$ the bulk of the crystals become amorphous while $\mathrm{CaO}$ particles form at the surface of the crystals [19,27]. Eddisford et al. [20] have reported that a recovery process becomes appreciable above a fluence rate of about $80 \mathrm{~A} \mathrm{~cm}^{-2}$. They also report that fluence seems to have no influence on damage below a value of about $1600 \mathrm{C} \mathrm{cm}^{-2}$ with no reduction of damage with sample cooling. Lastly, a transformation of the apatite hexagonal phase (space group: $\mathrm{P} 6_{3} / \mathrm{m}$ ) into a monoclinic phase has been suggested $[16,28]$.

\section{Accelerating voltage}

Senger et al. [17] have studied the ballistic damage induced on the ions inside the HAP unit cell by 300 and $400 \mathrm{kV}$ electrons by comparing the electrostatic binding energies of the ions-eventually increased by the covalent bond energy to the maximum transferable energy for the two voltages. These authors concluded that the hydroxyl and oxygen ions can be ejected and that after the creation of vacancies in the crystal unit cell, in particular the departure of the two hydroxyl ions, the calcium ions become more loosely bound and can be displaced. However, their conclusion that the phosphate ions were stable and not likely to be displaced is obviously in contradiction which the increase of the $\mathrm{Ca} / \mathrm{P}$ ratio observed by EDX and EELS.

More recent observation [20] show that the damage is more important as the voltage decreases which indicates that the damage process is dominated by radiolysis, which would explain the breaking of the $\mathrm{P}-\mathrm{O}$ covalent bonds and the displacement of the $\mathrm{P}^{5+}$ and $\mathrm{O}^{2-}$ ions outside the apatite bulk. In addition to this, the formation of dislocation lines and dislocation loops was observed at very high voltages, $2 \mathrm{mV}$, during the observation of HAP crystals [9].

\section{Temperature}

The temperature at a material irradiated by the electron beam inside an electron microscope is difficult to assess. It not only depends on the experimental parameters but also on the thermal diffusivity of the material itself [29]. Concerning calcium phosphate, indication on the temperature at the material level can be given by the existence or the absence of chemical reactions. In situ transformation of octacalcium phosphate (OCP) into hydroxyapatite reported by Nelson and McLean [30] did not show the presence of additional phase. However Brès et al. [25] have shown the existence of a transient phase in the transformation of calcium deficient apatite during TEM observation.

In the present paper, the effect of electron irradiation of stoichiometric hydroxyapatite $\left(\mathrm{Ca}_{10}\left(\mathrm{PO}_{4}\right)_{6}\left(\mathrm{OH}_{2}\right)\right.$ is investigated using STEM-EELS. The mass loss of Ca, $\mathrm{O}$ and $\mathrm{P}$ was followed for three different probe diameters and dose rates: $1 \mathrm{~nm}\left(\right.$ dose rate $\left.=26000 \mathrm{~A} \mathrm{~cm}^{-2}\right)$; $4 \mathrm{~nm}\left(\right.$ dose rate $\left.=160 \mathrm{~A} \mathrm{~cm}^{-2}\right)$ and $24 \mathrm{~nm}($ dose rate $=$ $\left.70 \mathrm{~A} \mathrm{~cm}^{-2}\right)$.

\section{Materials and methods}

Stoichiometric HAP single crystals were prepared as previously reported [23]. A Philips CM 30 ( $\mathrm{LaB}_{6}$ gun) operating in STEM mode at $200 \mathrm{keV}$ and fitted with a Gatan Enfina EELS spectrometer was used in this work for the low fluence rate experiments (standing probes of 4 and $24 \mathrm{~nm}$ nominal diameters corresponding to fluence rates of respectively around 70 and $160 \mathrm{~A} \mathrm{~cm}^{-2}$ ). HAP spectra were recorded with a spectrometer aperture of $2 \mathrm{~mm}$, an energy dispersion of $0.05 \mathrm{eV} / \mathrm{ch}$ and an energy resolution of 1-1.05 eV (full width at half maximum (FWHM) of the zero-loss peak) except for the oxygen K-edge spectra for the $4 \mathrm{~nm}$ probe size for which we used a $0.3 \mathrm{eV} / \mathrm{ch}$ energy dispersion to compensate signal weakness resulting in a lower energy resolution of around $1.8 \mathrm{eV}$. A JEOL2100F (field emission gun) operating in STEM mode at $200 \mathrm{keV}$ and fitted with a Gatan GIF quantum was used in this work for the high fluence rate experiments (standing probe of $1 \mathrm{~nm}$ nominal diameter corresponding to a fluence rate of around $25000 \mathrm{~A} \mathrm{~cm}^{-2}$ ). HAP spectra were recorded with a spectrometer aperture of $2.5 \mathrm{~mm}$, an energy dispersion of $0.05 \mathrm{eV} / \mathrm{ch}$ and an energy resolution of around $0.9 \mathrm{eV}$ (full width at half maximum [FWHM] of the zeroloss peak).

\section{Results and discussion}

A typical bright field TEM image of the HAP nanoparticles used in this work is shown in Figure 1. The initial stage of sample examination is always critical as a minimum amount of time is always required for selecting the sample zone itself and for performing the initial microscope adjustments. Even if the experimentalist tries to reduce this delay, the sample receives a minimum dose of electrons and the possibility of initial sample modification cannot be excluded.

We have obtained contradictory information at the initial irradiation stages. The examination of the low loss spectrum from 0.1 to $5 \mathrm{~s}$ indicates no modification of the signal stability, shape and intensity which indicates no initial modification of the HAP structure under the beam even at a fluence rate of $160 \mathrm{~A} \mathrm{~cm}^{-2}$ (spot size $4 \mathrm{~nm}$ ). Figure 2 shows the evolution of the HA low loss signal as function of the total irradiation time. The parameters of this figure are: STEM mode, probe size $4 \mathrm{~nm}$, acquisition time for each spectrum $0.1 \mathrm{~s}$ and a dose rate 


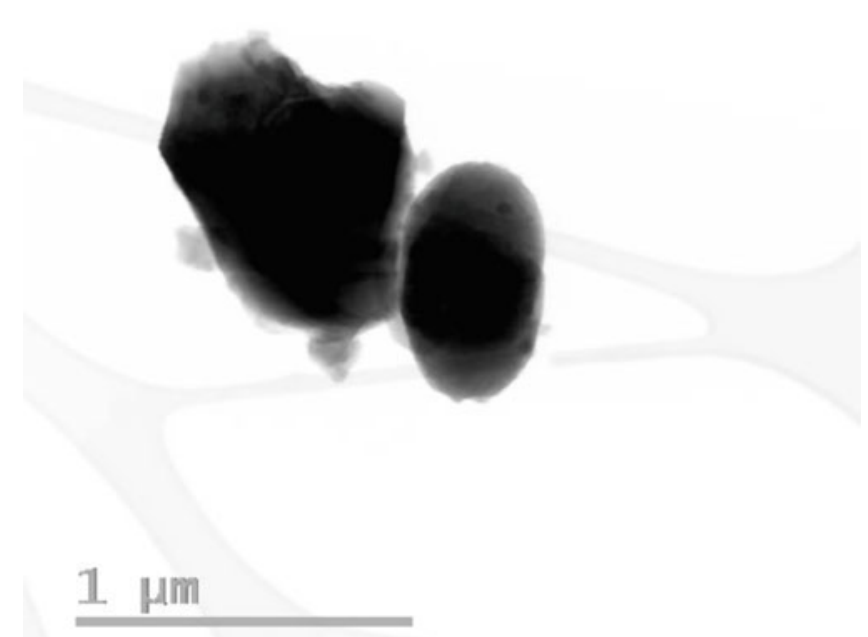

Fig. 1. STEM bright field image of the HAP nanoparticles.

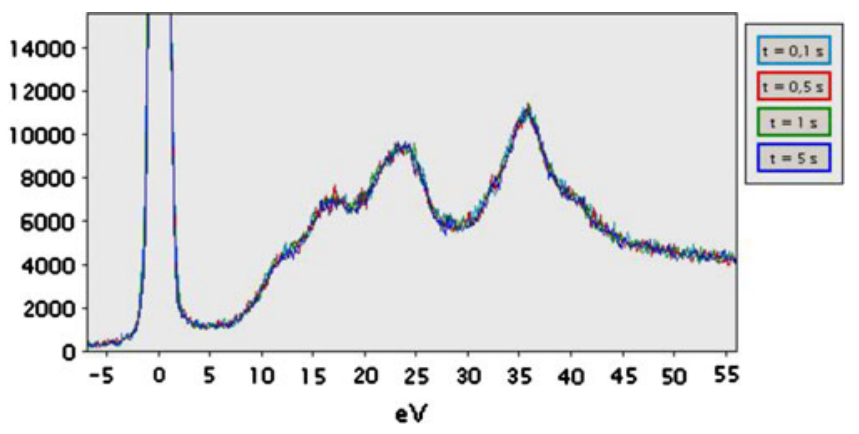

Fig. 2. Evolution of the HA low loss signal as function of the total irradiation time. STEM mode, probe size $4 \mathrm{~nm}$ acquisition time for each spectrum $0.1 \mathrm{~s}$, dose rate $160 \mathrm{~A} \mathrm{~cm}^{-2}$.

$160 \mathrm{~A} \mathrm{~cm}^{-2}$. The analysis of the effect of two probe sizes (4 and $24 \mathrm{~nm}$ ), with different dose rates (fluence rates; 70 and $160 \mathrm{~A} \mathrm{~cm}^{-2}$ ) over a range of doses (fluence: from $350 \mathrm{C} \mathrm{cm}^{-2}$ to $2400 \mathrm{C} \mathrm{cm}^{-2}$ ) on the possible mass loss of the different chemical elements $(\mathrm{Ca}, \mathrm{O}$ and $\mathrm{P})$ of the sample studied is described on Table 1 and Figure 3. The presented spectra correspond to raw data in the case of phosphorus and to raw data after background subtraction in the case of calcium and oxygen.
Careful examination shows that the spectra obtained are well resolved from the very first observation and remain resolved throughout the full irradiation times (from 5 to $15 \mathrm{~s}$ ) regardless the chemical element and for both probe sizes and fluence rates values (probe size: $4 \mathrm{~nm}$, dose rate: $160 \mathrm{~A} \mathrm{~cm}^{-2}$ and probe size: $24 \mathrm{~nm}$, dose rate $70 \mathrm{~A} \mathrm{~cm}^{-2}$ ) (Fig. 3).

Moreover fine observation of the HAP oxygen K-edge signals (bottom line in Figure 3) reveals stable apatite characteristic peaks located at $536 \mathrm{eV}$ and $539 \mathrm{eV}$ when, for instance, there is just a shoulder at $536 \mathrm{eV}$ in the case of $\beta$-tricalcium phosphate $(\beta$-TCP) oxygen K-edge signals (Fig. 4) [22]. On the other hand a pre-peak located at $531 \mathrm{eV}$ is present in the $\beta$-TCP signal and missing in the HAP signal. In Figure 4 this pre-peak appears to be sensitive during the irradiation of $\beta$-TCP [23] so that we cannot exclude its quick disappearance in the very early stages of irradiation of HAP.

Furthermore, no observable formation of $\mathrm{CaO}$ takes place during the irradiation, or at least not detected for the experimental device used in this work. $\mathrm{CaO}$, calcium $\mathrm{L}_{2,3}$ edge signal presents a typical shape characterized by a splitting into two of the $\mathrm{L}_{2,3}$ lines [23]. Figure 5 presents the typical calcium $\mathrm{L}_{2,3}$ signal recorded in case of $\mathrm{CaO}$ formation. The splitting is not observed in our HAP spectra. The absence of effect of the dose (fluence) from 350 to $2400 \mathrm{C} \mathrm{cm}^{-2}$ on the spectra is in agreement with the results obtained by Eddisford et al. [20] who have shown no variation of the $\mathrm{Ca} / \mathrm{P}$ ratio for fluence up to $16000 \mathrm{C} \mathrm{cm}^{-2}$. With regards to the effect of the dose rates (fluence rates), Eddisford et al. [20] have found unchanged $\mathrm{Ca} / \mathrm{P}$ stoichiometric values around $100 \mathrm{~A} \mathrm{~cm}^{-2}$. However, higher $\mathrm{Ca} / \mathrm{P}$ ratios were obtained both below and above $100 \mathrm{~A} \mathrm{~cm}^{-2}$. This variation is more dramatic at high doses (fluences) up to $16000 \mathrm{~cm}^{-2}$. It was also observed that the low values of both electron dose rates and doses (from 350 to $2400 \mathrm{C} \mathrm{cm}^{-2}$ ) avoid mass loss. Considering the results shown by Eddisford et al. [20], the absence of mass loss observed in this work can be explained by the low values of dose (fluence) used (up to $2400 \mathrm{C} \mathrm{cm}^{-2}$ ) which reduces the effect of the dose rate.

The difference of the probe sizes is difficult to evaluate independently of other parameters. In the present case, the slight noise increase observed on the spectra obtained with a $4 \mathrm{~nm}$ probe can be due to both the reduced number of incident electrons (16 times less) and to the smaller number of OHAP unit cells probed (40 times less) compared to the $24 \mathrm{~nm}$ probe size.

At the higher dose rates obtained from a field emission gun $(\mathrm{FEG})\left(\right.$ dose rate $=26000 \mathrm{~A} \mathrm{~cm}^{-2}$, probe size $=1 \mathrm{~nm}$, spectral resolution $\sim 0.9 \mathrm{eV})$, the spectra show the

Table 1. Probe sizes, dose and dose rates.

\begin{tabular}{ccccc}
\hline Probe diameter & $\begin{array}{c}\text { Dose rate } \\
\left(\mathrm{A} \mathrm{cm}^{-2}\right)\end{array}$ & $\begin{array}{c}\text { Dose } \\
\left(\mathrm{C} \mathrm{cm}^{-2}\right) 5 \mathrm{~s}\end{array}$ & $\begin{array}{c}\text { Dose } \\
\left(\mathrm{C} \mathrm{cm}^{-2}\right) 10 \mathrm{~s}\end{array}$ & $\begin{array}{c}\text { Dose } \\
\left(\mathrm{C} \mathrm{cm}^{-2}\right) 15 \mathrm{~s}\end{array}$ \\
\hline $1 \mathrm{~nm} \mathrm{FEG}$ & 25000 & 125000 & 250000 & 375000 \\
$4 \mathrm{~nm} \mathrm{LaB}$ & 160 & 800 & 1600 & 2400 \\
$24 \mathrm{~nm} \mathrm{LaB}_{6}$ & 70 & 350 & 700 & 1050 \\
\hline
\end{tabular}


$\mathrm{Ca}$
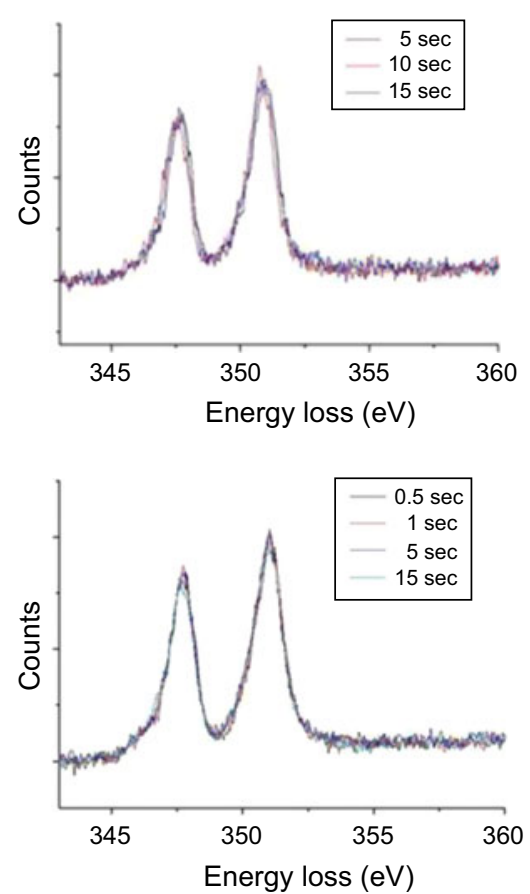

$\mathrm{O}$
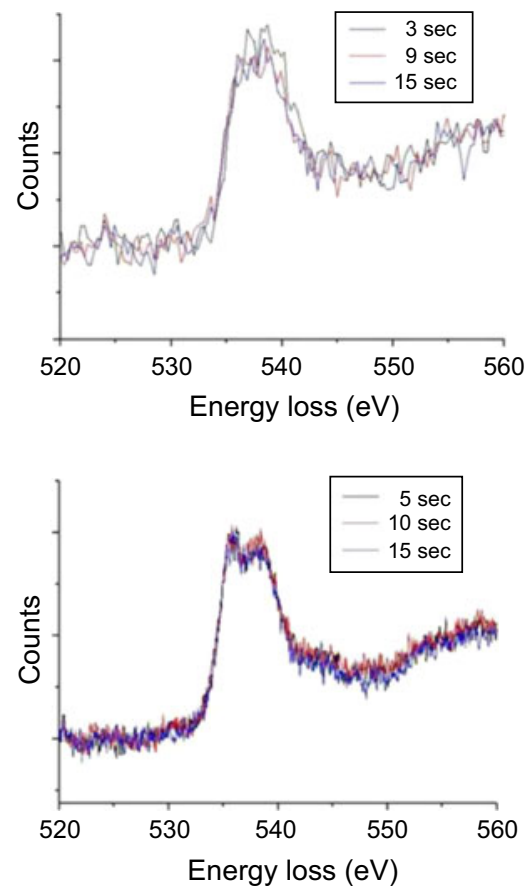


Fig. 3. Effect of the probe size (top line: probe size: $4 \mathrm{~nm}$, dose rate $160 \mathrm{~A} \mathrm{~cm}^{-2}$, spectra acquisition time $5 \mathrm{~s}$ or $3 \mathrm{~s}$; bottom line: $24 \mathrm{~nm}$, dose rate $70 \mathrm{~A} \mathrm{~cm}^{-2}$, spectra acquisition time $0.5 \mathrm{~s}$ or $5 \mathrm{~s}$ ) on the evolutions during irradiation as a function of the total irradiation time of the $\mathrm{Ca}, \mathrm{O}$ and $\mathrm{P}$ signals in hydroxyapatite. The loss of resolution due to increased energy dispersion of the spectrometer prevents observing of the two HAP characteristic peaks in the oxygen K-edge signals corresponding to the $4 \mathrm{~nm}$ probe size.

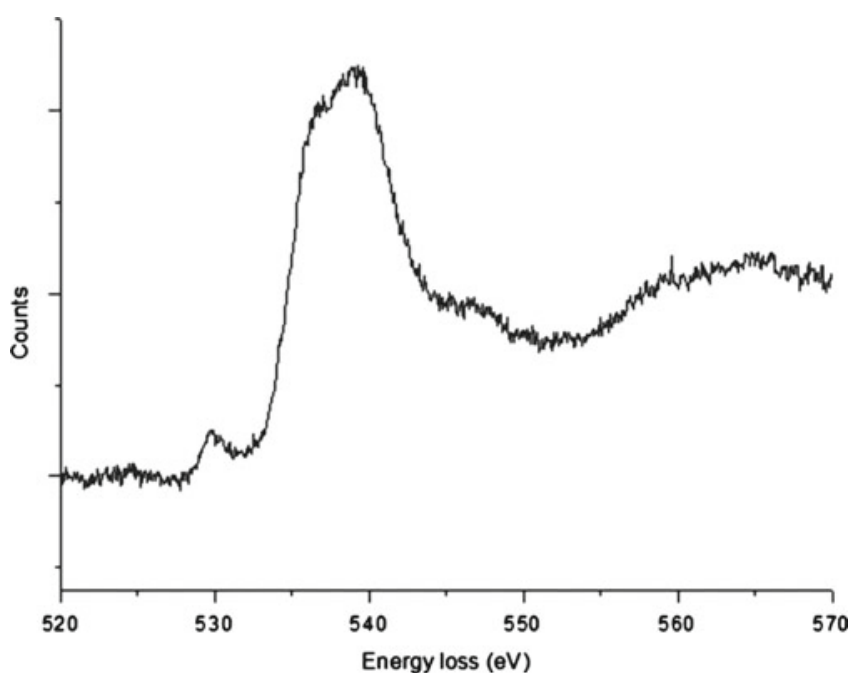

Fig. 4. $\beta$-TCP Oxygen K-edge signal showing a pre-peak at $531 \mathrm{eV}$ and a shoulder at $536 \mathrm{eV}$ (probe size $24 \mathrm{~nm}$, acquisition time $10 \mathrm{~s})$.

following transformations at observed at prolonged irradiation times:

- Low loss signal (Fig. 6): a change of shape hence a structural change is observed. This structural change is very quick as revealed by the differences between low loss signal at $t=0.1 \mathrm{~s}$ in Figure 6 and the low

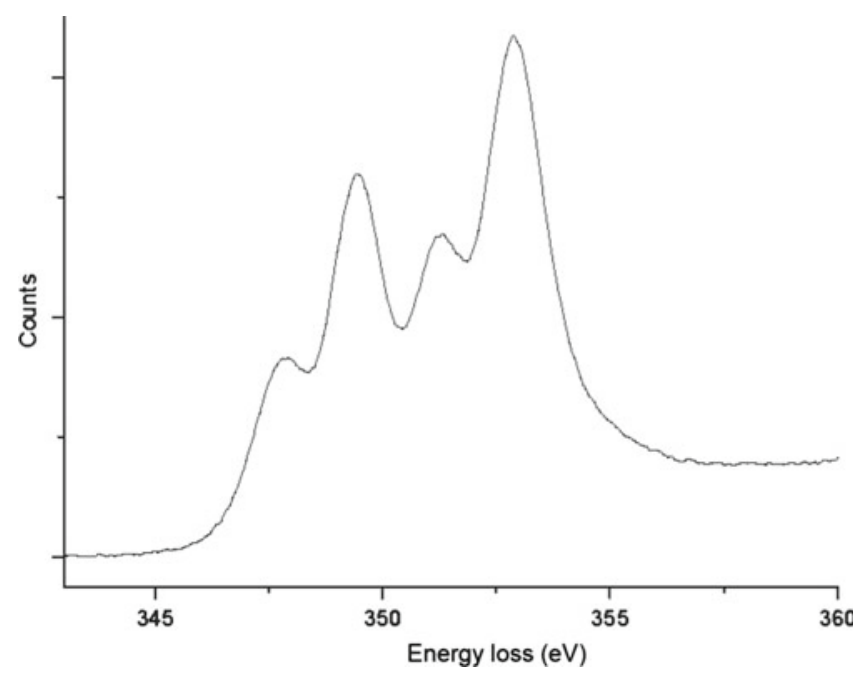

Fig. 5. $\mathrm{CaO}$ calcium $\mathrm{L}_{2,3}$ edge signal (probe size $24 \mathrm{~nm}$, dispersion $0.05 \mathrm{eV} / \mathrm{ch}$ ).

loss signals in Figure 2 at lower dose rate. Moreover a continuous loss of mass is revealed by these spectra. However the rate of this mass loss seems to reduce with irradiation time;

- Phosphorus $\mathrm{L}_{2,3}$ edge signal (Fig. 7): a continuous mass loss is observed, the phosphorus signal is faint at the highest irradiation times; 


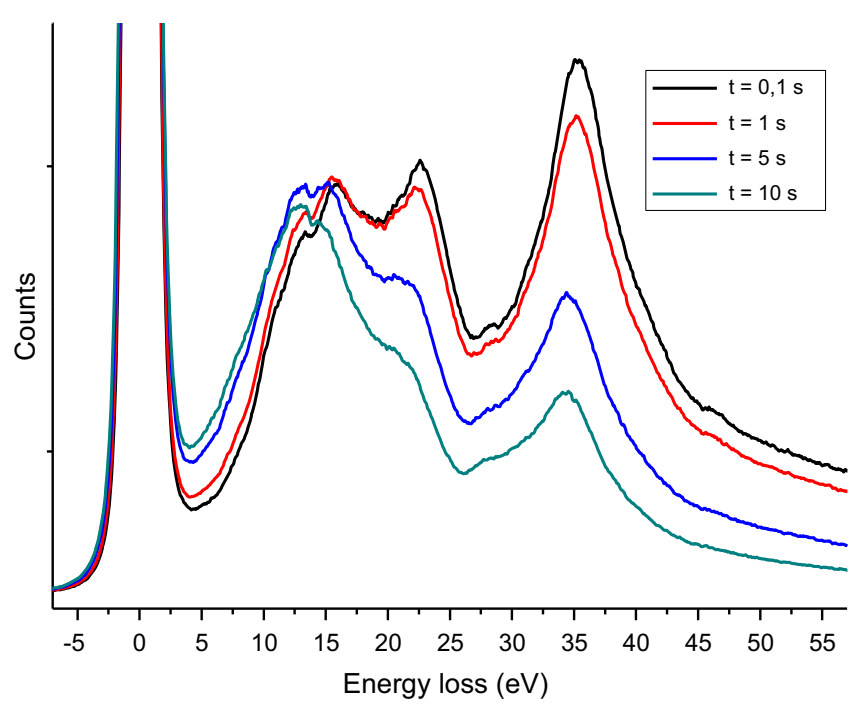

Fig. 6. Evolution of the HA low loss signal as a function of the total irradiation time. Probe size $1 \mathrm{~nm}$; acquisition time for each spectrum $0.1 \mathrm{~s}$, dose rate $25000 \mathrm{~A} \mathrm{~cm}^{-2}$.

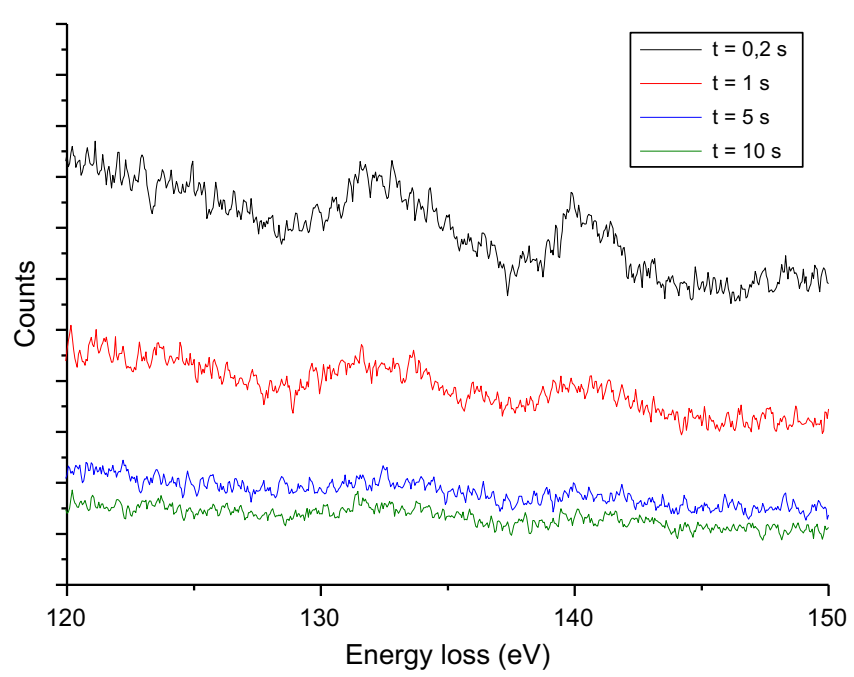

Fig. 7. Evolution of the HA phosphorus signal as a function of the total irradiation time. Probe size $1 \mathrm{~nm}$; acquisition time for each spectrum $0.2 \mathrm{~s}$, dose rate $25000 \mathrm{~A} \mathrm{~cm}^{-2}$. Phosphorus $\mathrm{L}_{2,3}$ edge signals is not subtracted from the background.

- Calcium $\mathrm{L}_{2,3}$ edge signal (Fig. 8): the mass loss is small between $5 \mathrm{~s}$ and $10 \mathrm{~s}$. Beyond $5 \mathrm{~s}$, a doubling of the peaks characteristic of the formation of $\mathrm{CaO}$ is observed. This is not as obvious as for the pure $\mathrm{CaO}$ sample (see Fig. 5), it is likely that we have a mixture of phases. Furthermore, the signal is weak as it was obtained after an important mass loss;

- Oxygen K-edge signal (Fig. 9): an important variation of the edge shape and a strong variation of mass loss is observed up to $8 \mathrm{~s}$ of irradiation but the mass variation is small beyond $8 \mathrm{~s}$ of irradiation. This change of shape also indicates a quick structural change of the sample.

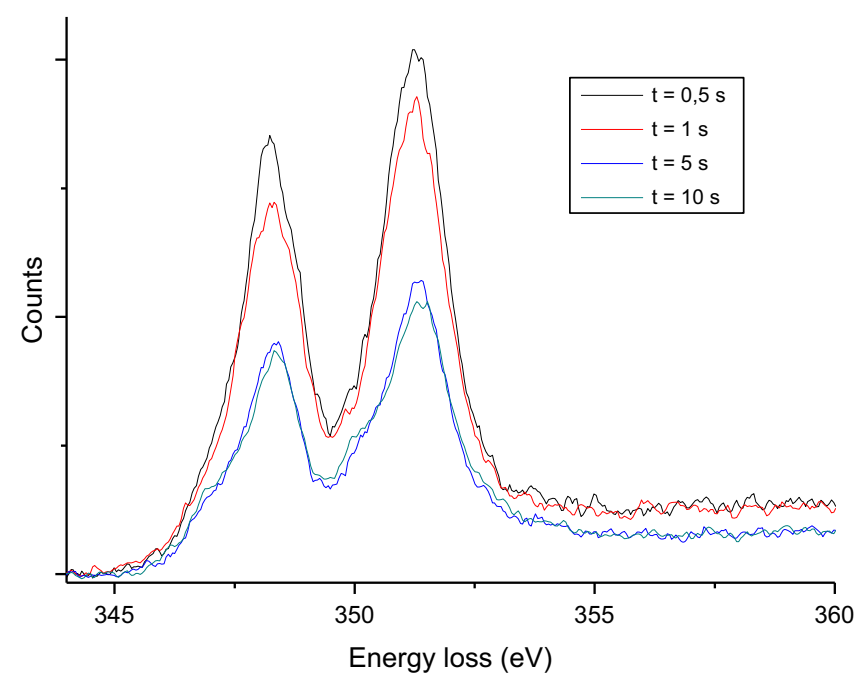

Fig. 8. Evolution of the HA calcium signal as a function of the total irradiation time. Probe size $1 \mathrm{~nm}$; acquisition time for each spectrum $0.5 \mathrm{~s}$, dose rate $25000 \mathrm{~A} \mathrm{~cm}^{-2}$. Calcium $\mathrm{L}_{2,3}$ edge signal is subtracted from the background.

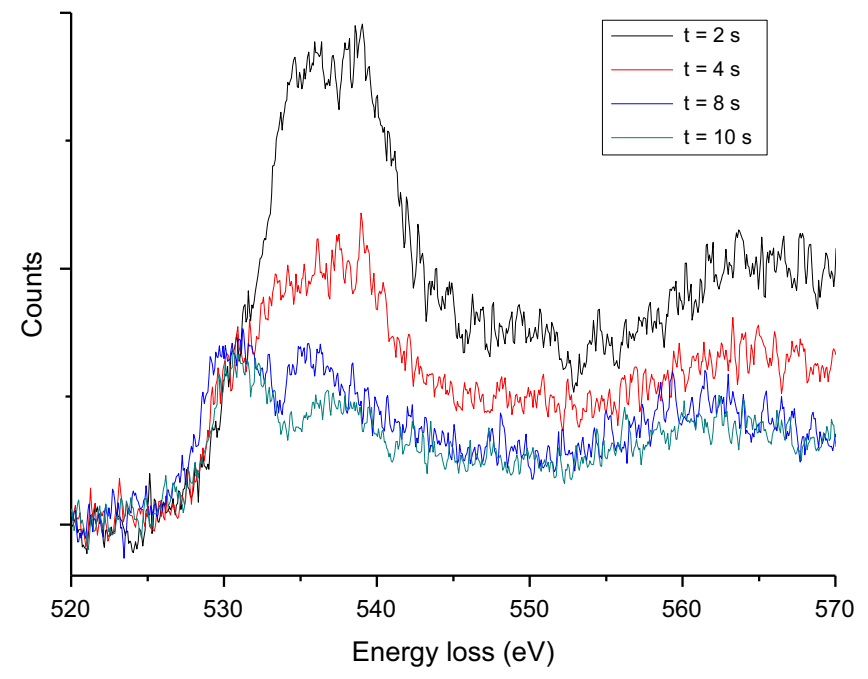

Fig. 9. Evolution of the HA oxygen signal as a function of the total irradiation time. Probe size $1 \mathrm{~nm}$; acquisition time for each spectrum $2 \mathrm{~s}$, dose rate $25000 \mathrm{~A} \mathrm{~cm}^{-2}$. Oxygen K-edge signal is subtracted from the background.

\section{Conclusion}

In this work, we have investigated the effect of electron irradiation on stoichiometric hydroxyapatite $\left(\mathrm{Ca}_{10}\left(\mathrm{PO}_{4}\right)_{6}\right.$ $\left.\left(\mathrm{OH}_{2}\right)\right)$ using STEM-EELS using a $\mathrm{LaB}_{6}$ and a field emission gun equipped microscopes. We have obtained contradictory information on the initial irradiation stages. No modification of the low loss EELS spectra was observed between $0.1 \mathrm{~s}$ and $5 \mathrm{~s}$, but we cannot exclude that the absence - on the HA spectra, of the pre-peak observed on $\beta$-TCP spectra is due to initial damage. We did not observe mass loss in the low-loss and in the different 
elemental (Ca, P, O) spectra during irradiation (no change of spectra intensity) for the two different probe diameters: $4 \mathrm{~nm}$ (dose rate $=160 \mathrm{~A} \mathrm{~cm}^{-2}$ ) and $24 \mathrm{~nm}$ (dose rate $=70 \mathrm{~A} \mathrm{~cm}^{-2}$ ), although the corresponding dose rates are different. It is important to note that detailed spectra of all chemical elements inside the hydroxyapatite lattice (except for $\mathrm{H}$ ) using a probe diameter as small as $4 \mathrm{~nm}$ can be obtained. No formation of $\mathrm{CaO}$ was observed in all the spectra.

Signal modifications are observed at the dose rate obtained with the FEG $\left(\sim 25000 \mathrm{~A} \mathrm{~cm}^{-2}\right.$, probe diameter $=1 \mathrm{~nm}$ ) for the low loss, $\mathrm{Ca}$, $\mathrm{O}$ and $\mathrm{P}$ signals. This implies the necessity of using lower dose rates for the study of HA samples.

This result will be very useful for the examination of nanosized particles or for investigating fine structural variations across single particles.

We acknowledge the technical support from the Reims ICT IBiSA Biological Imaging Centre. The authors with to thank Dr. Alexandre MUSSI (UMET, Lille, France) for help. JRG acknowledges the CONACYT (Ref. No. 203257) and the PASPADGAPA-UNAM program (Com. 053/2013) for the economical support for the sabbatical stay at the University of Lille 1, France.

\section{References}

1. H. Sicher, Orban's Oral Histology and Embryology (Mosby, Saint Louis, 1962)

2. R. Lakes, Nature 361, 511 (1993)

3. C. Rey, C. Combes, C. Drouet, H. Sfihi, A. Barroug, Mater. Sci. Eng. C 27, 198 (2007)

4. M. Okazaki, Y. Yoshida, S. Yamaguchi, M. Kaneno, J.C. Elliott, Biomaterials 22, 2459 (2001)

5. D. Eichert, C. Drouet, H. Sfihia, C. Rey, C. Combes, Nanocrystalline Apatite-Based Biomaterials (Nova, Science Publishers, New York, 2011)

6. E.I. Suvorova, V.V. Klechkovskaya, V.F. Komarov, A.V. Severin, I.V. Melikhov, P.A. Buffat, Crystallogr. Rep. 51, $881(2006)$

7. R.M. Imanov, V.V. Klechkovskaya, E.I. Suvorova, Crystallogr. Rep. 56, 650 (2011)
8. É.F. Brès, D. Cherns, R. Vincent, J.-P. Morniroli, Acta Crystallogr. B 49, 56 (1993)

9. T. Aoba, J. Takahashi, T. Yagi, M. Okazaki, Y. Moriwaki, J. Dent. Res. 57, 708 (1978)

10. R.F. Egerton, P. Li, M. Malac, Micron 35, 399 (2004)

11. I.-T. Bae, Y. Zhangn, W.J. Weber, M. Ishimaru, Y. Hirotsu, M. Higuchi, Nucl. Instrum. Methods Phys. Res. B 266, 3037 (2008)

12. J. Reyes-Gasga, R. Garcia-Garcia, Radiat. Phys. Chem. 64, 359 (2002)

13. D.G.A. Nelson, J.D. McLean, J.V. Sanders, Radiation Effects Letters 68, 51 (1982)

14. J. Reyes-Gasga, R. Garcia-Garcia, E.F. Brès, Physica B: Condens. Matter 404, 1867 (2009)

15. Z.L. Dong, T.J. White, K. Sun, L.M. Wang, R.C. Ewing, J. Am. Ceram. Soc. 88, 184 (2005)

16. S. Nicolopoulos, J.M. Gonzalez-Calbet, M.P. Alonso, M.T. Gutierrez-Rios, M.I. de Frutos, M. Vallet-Regi, J. Solid State Chem. 116, 265 (1995)

17. B. Senger, E.F. Brès, J.L. Hutchison, J.-C. Voegel, R.M. Frank, Philos. Mag. A 65, 665 (1992)

18. É.F. Brès, G. Moebus, H.J. Kleebe, G. Pourroy, J. Werkmann, G. Ehret, J. Cryst. Growth 129, 149 (1993)

19. E.F. Brès, J.L. Hutchison, B. Senger, J.-C. Voegel, Ultramicros. 35, 305 (1991)

20. P. Eddisford, A. Brown, R. Brydson, J. Phys.: Conf. Ser. 126, 012008 (2008)

21. S.Ch. Liou, S.Y. Chen, H.Y. Lee, J.S. Bow, Biomaterials 25, 189 (2004)

22. G. Gregori, H.J. Kleebe, H. Mayra, G. Ziegler, J. Eur. Ceram. Soc. 26, 1473 (2006)

23. R. Drevet, H. Benhayoune, J. Michel, Journal of Biomaterials and Tissue Engineering 1, 68 (2011)

24. R.B. Heimanna, R. Wirth, Biomaterials 27, 823 (2006)

25. É.F. Brès, T. Duhoo, N. Leroy, J. Lemaitre, Zeitschrift für Metallkunde 96, 503 (2005)

26. R.M. Flower, Earth Planet. Sci. Lett. 277, 148 (2009)

27. A. Meldrum, L.M. Wang, R.C. Ewing, Am. Mineral. 82, 858 (1997)

28. J. Reyes-Gasga, E.L. Martinez-Piñeiro, É.F. Brès, J. Microsc. 248, 102 (2012)

29. L. Reimer, Transmission Electron Microscopy, Springer Series in Optical Sciences (Springer, Berlin, 1984)

30. D.G.A. Nelson, J.D. McLean, Calcif. Tissue Int. 36, 219 (1984) 